JOURNAL OF PUBLIC HEALTH INOVATION, VOL. 02 NO.01. DESEMBER 2021

DOI: $\underline{10.34305 / \text { jphi.v2i1.353 }}$
Ciptaan disebarluaskan di bawah

Lisensi Creative Commons Atribusi-

NonKomersial-BerbagiSerupa 4.0

\title{
DETERMINAN PERILAKU MEROKOK PADA REMAJA PUTRI
}

\author{
Nia Musniati ${ }^{1}$, Retno Mardhiati ${ }^{1}$, Zulazmi Mamdy ${ }^{1}$, Hamdan $^{2}$ \\ ${ }^{1}$ Universitas Muhammadiyah Prof. DR. HAMKA \\ ${ }^{2}$ STIKes Kuningan \\ niamusniati@uhamka.ac.id
}

\begin{abstract}
Abstrak
Indonesia menjadi Negara dengan jumlah perokok remaja terbanyak di dunia. Penelitian ini bertujuan untuk mengetahui determinan perilaku merokok pada remaja putri di SMAN 6 Jakarta tahun 2016. Metode penelitian analitik kuantitatif dengan desain case control. Sampel penelitian ini berjumlah 63 remaja putri, Sampel kelompok kasus adalah remaja putri yang perokok (21 orang) dan sampel kelompok kontrol adalah remaja putri yang tidak perokok (42 orang). Pengumpulan data dengan kuesioner pada April 2016. Analisis yang dilakukan adalah univariat, bivariat dengan Chi-Square, dan multivariat dengan regresi logistik berganda. Hasil bivariat menunjukkan terdapat hubungan bermakna antara keyakinan $(p=0,012)$, sikap $(p=0,000)$, pekerjaan ibu $(p=0,031)$, pekerjaan ayah $(p=0,004)$, akses rokok $(p=0,000)$, perilaku merokok saudara (kakak) $(p=0,009)$, peran keluarga $(p=0,021)$, teman perempuan perokok $(p=0,000)$, teman laki-laki perokok $(p=0,000)$ dengan perilaku merokok remaja putri. Hasil multivariat menunjukkan variabel akses rokok merupakan variabel yang paling berpengaruh terhadap perilaku merokok remaja putri.
\end{abstract}

Kata Kunci: determinan, akses rokok, perilaku merokok, remaja putri

\section{Pendahuluan}

Global Youth Tobacco Survey 2014 menyebutkan Indonesia menjadi Negara dengan jumlah perokok remaja terbanyak di dunia. Selain itu, menurut jenis kelamin ditemukan 33,9\% remaja laki-laki dan 2,5\% remaja perempuan penghisap rokok.
Berdasarkan umur, ditemukan trend yang meningkat pada usia remaja yaitu usia 1014 tahun dan 15-19 tahun dengan usia pertama kali merokok paling tinggi adalah 15-19 tahun (Kemenkes RI, 2014).

Kecanduan rokok pada perempuan berdampak peningkatan kematian akibat 
JOURNAL OF PUBLIC HEALTH INOVATION, VOL. 02 NO.01. DESEMBER 2021

DOI: $10.34305 /$ jphi.v2i1.353

merokok yang dahulunya lebih banyak dialami laki-laki sekarang risiko itu juga mengancam perempuan yang merokok. Risiko akibat rokok pada perempuan cenderung meningkatkan kanker payudara, kanker leher rahim, keguguran dan penyakit tidak menular lainnya (Kemenkes RI, 2018). Dampak perilaku merokok pada remaja ialah prestasi belajar terganggu, mengganggu perkembangan paru-paru, menurunkan sistem imun, sering timbul masalah kulit dan plak gigi, kecanduan, depresi, insomnia, mudah marah, dan masalah mental lainnya (Kemenkes RI, 2019).

Hasil pengamatan yang dilakukan penulis kepada 50 remaja putri pada 22 Januari 2016 untuk menggali permasalahan yang ada di SMAN 6 Jakarta, ditemukan 16 remaja putri menyatakan pernah merokok dan ada 6 remaja putri yang menyatakan aktif merokok sampai saat ini. Penelitian ini bertujuan untuk mengetahui determinan perilaku merokok pada remaja putri di SMAN 6 Jakarta Tahun 2016.

\section{Metode}

Penelitian ini adalah penelitian analitik kuantitatif dengan desain case control. Total sampel pada penelitian ini 63
Ciptaan disebarluaskan di bawah

Lisensi Creative Commons Atribusi-

NonKomersial-BerbagiSerupa 4.0

remaja putri. Sampel kelompok kasus adalah remaja putri yang perokok (21 orang) dan sampel kelompok kontrol adalah remaja putri yang tidak perokok (42 orang) dengan perbandingan kasus dan control 1 banding 2 . Teknik sampling untuk kelompok kasus adalah sampling jenuh. Teknik sampling untuk kelompok kontrol adalah simple random sampling. Penelitian ini dilakukan pada Januari - Agustus 2016 dengan pengumpulan data pada April 2016.

Metode pengumpulan data pada penelitian ini menggunakan data primer yang dikumpulkan menggunakan kuesioner yang berisikan pertanyaan yang terdiri dari 20 variabel yaitu : Perilaku merokok remaja putri, umur, pengetahuan, keyakinan, sikap, tingkat stres, pendidikan ibu, pendidikan ayah, pekerjaan ibu, pekerjaan ayah, akses terhadap rokok, uang saku, perilaku merokok ibu, perilaku merokok ayah, perilaku merokok saudara (kakak), peran keluarga, teman perempuan perokok, teman laki-laki perokok, peran teman sebaya dan keterpajanan iklan rokok. Sedangkan data sekunder dikumpulkan dari pihak sekolah berupa profil sekolah dan daftar remaja putri. Data penelitian dianalisis secara univariat, bivariat dengan Chi-Square dan 
JOURNAL OF PUBLIC HEALTH INOVATION, VOL. 02 NO.01. DESEMBER 2021

DOI: $10.34305 /$ jphi.v2i1.353

multivariat dengan regresi logistik berganda.

\section{Hasil}

Analisis bivariat menunjukkan bahwa terdapat hubungan yang signifikan antara keyakinan $(p=0,012)$, sikap $(p=$ $0,000)$, pekerjaan ibu $(p=0,031)$, pekerjaan ayah $(p=0,004)$, akses rokok $(p=0,000)$, perilaku merokok saudara (kakak) ( $p=$ $0,009)$, peran keluarga $(p=0,021)$, teman perempuan perokok $(p=0,000)$, dan teman laki-laki perokok $(p=0,000)$ dengan perilaku merokok remaja putri. Selain itu, tidak terdapat hubungan yang signifikan antara umur, pengetahuan, tingkat stres, pendidikan ibu, pendidikan ayah, uang saku, perilaku merokok ibu, perilaku merokok ayah, peran teman, dan keterpajanan iklan rokok dengan perilaku merokok remaja putri $(p=>0,05)$ (Tabel 1).
Ciptaan disebarluaskan di bawah

Lisensi Creative Commons Atribusi-

NonKomersial-BerbagiSerupa 4.0

Internasional

Hasil analisis multivariat didapat variabel yang berhubungan bermakna (dominan) dengan perilaku merokok remaja putri adalah variabel akses terhadap rokok dan teman perempuan perokok $(p<0,05)$. Variabel akses rokok paling besar pengaruhnya terhadap perilaku merokok remaja putri SMAN 6 Jakarta dengan OR 6175,74 artinya responden yang memiliki akses terhadap rokok mudah risiko untuk merokok 6175,74 kali dibandingkan responden yang memiliki akses terhadap rokok sulit setelah dikontrol variabel keyakinan, sikap, tingkat stress, pekerjaan ibu, pekerjaan ayah, uang saku, perilaku merokok saudara (kakak), peran keluarga, teman perempuan perokok. Hasil pemodelan terakhir memiliki nilai $\mathrm{R}^{2} 0,854$, artinya ke 10 variabel independen tersebut dapat menjelaskan variasi variabel perilaku merokok remaja putri sebesar $85,4 \%$ (Tabel 2).

Tabel 1. Distribusi Kasus Kontrol Berdasarkan Determinan Perilaku Merokok Remaja Putri

\begin{tabular}{|c|c|c|c|c|c|c|c|}
\hline \multirow{3}{*}{ No } & \multirow{3}{*}{ Variabel } & \multicolumn{4}{|c|}{$\begin{array}{c}\text { Perilaku Merokok Remaja } \\
\text { Putri }\end{array}$} & \multirow{4}{*}{ 95\% CI (Lower-Upper) } & \multirow{4}{*}{ p-value } \\
\hline & & \multicolumn{2}{|c|}{ Perokok } & \multicolumn{2}{|c|}{ Tidak perokok } & & \\
\hline & & $\mathbf{n}$ & $\%$ & $\mathbf{N}$ & $\%$ & & \\
\hline \multirow[t]{3}{*}{1} & Umur & & & & & & \\
\hline & Remaja Madya & 16 & 76,2 & 29 & 69,0 & $1,434(0,433-4,755)$ & 0,554 \\
\hline & Remaja Awal & 5 & 23,8 & 13 & 31,0 & & \\
\hline 2 & Pengetahuan & & & & & & \\
\hline
\end{tabular}


JOURNAL OF PUBLIC HEALTH INOVATION, VOL. 02 NO.01. DESEMBER 2021

DOI: $\underline{10.34305 / j p h i . v 2 i 1.353}$
Ciptaan disebarluaskan di bawah

Lisensi Creative Commons Atribusi-

NonKomersial-BerbagiSerupa 4.0 Internasional

\begin{tabular}{|c|c|c|c|c|c|c|c|}
\hline & Rendah & 11 & 52,4 & 19 & 45,2 & $1,333(0,466-3,805)$ & 0,593 \\
\hline & Tinggi & 10 & 47,6 & 23 & 54,8 & & \\
\hline \multirow[t]{3}{*}{3} & Keyakinan & & & & & \multirow{3}{*}{$4,000(1,317-12,152)$} & \multirow{3}{*}{0,012} \\
\hline & Rendah & 14 & 66,7 & 14 & 33,3 & & \\
\hline & Tinggi & 7 & 33,3 & 28 & 66,7 & & \\
\hline \multirow[t]{3}{*}{4} & Sikap & & & & & \multirow{3}{*}{$22,000(5,279-91,682)$} & \multirow{3}{*}{0,000} \\
\hline & Tidak baik & 18 & 85,7 & 9 & 21,4 & & \\
\hline & Baik & 3 & 14,3 & 33 & 78,6 & & \\
\hline \multirow[t]{3}{*}{5} & Tingkat Stres & & & & & \multirow{3}{*}{$2,200(0,739-6,549)$} & \multirow{3}{*}{0,153} \\
\hline & Stres & 14 & 66,7 & 20 & 47,6 & & \\
\hline & Tidak stress & 7 & 33,3 & 22 & 52,4 & & \\
\hline \multirow[t]{3}{*}{6} & Pendidikan Ibu & & & & & \multirow{3}{*}{$0,611(0,147-2,547)$} & \multirow{3}{*}{0,735} \\
\hline & Rendah & 3 & 14,3 & 9 & 21,4 & & \\
\hline & Tinggi & 18 & 85,7 & 33 & 78,6 & & \\
\hline \multirow[t]{3}{*}{7} & Pendidikan Ayah & & & & & \multirow{3}{*}{$0,708(0,167-3,004)$} & \multirow{3}{*}{0,738} \\
\hline & Rendah & 3 & 14,3 & 8 & 19,0 & & \\
\hline & Tinggi & 18 & 85,7 & 34 & 81,0 & & \\
\hline \multirow[t]{3}{*}{8} & Pekerjaan Ibu & & & & & \multirow{3}{*}{$3,520(1,090-11,371)$} & \multirow{3}{*}{0,031} \\
\hline & Bekerja & 16 & 76,2 & 20 & 47,6 & & \\
\hline & Ibu RT & 5 & 23,8 & 22 & 52,4 & & \\
\hline \multirow[t]{3}{*}{9} & Pekerjaan Ayah & & & & & \multirow{3}{*}{$5,000(1,619-15,440)$} & \multirow{3}{*}{0,004} \\
\hline & Tidak Full & 14 & 66,7 & 12 & 28,6 & & \\
\hline & Full & 7 & 33,3 & 30 & 71,4 & & \\
\hline 10 & Akses Rokok & & & & & & \\
\hline & Mudah & 20 & 95,2 & 10 & 23,8 & $64,000(7,604-538,656)$ & 0,000 \\
\hline & Sulit & 1 & 4,8 & 32 & 76,2 & & \\
\hline 11 & Uang saku & & & & & & \\
\hline & Besar & 13 & 61,9 & 18 & 42,9 & $2,167(0,742-6,329)$ & 0,154 \\
\hline & Kecil & 8 & 38,1 & 24 & 57,1 & & \\
\hline 12 & Perilaku Merokok Ibu & & & & & & \\
\hline & Perokok & 4 & 19,0 & 5 & 11,9 & $1,741(0,415-7,310)$ & 0,466 \\
\hline & Tidak Perokok & 17 & 81,0 & 37 & 88,1 & & \\
\hline 13 & Perilaku Merokok Ayah & & & & & & \\
\hline & Perokok & 12 & 57,1 & 20 & 47,6 & $1,467(0,511-4,213)$ & 0,476 \\
\hline & Tidak Perokok & 9 & 42,9 & 22 & 52,4 & & \\
\hline 14 & Perilaku Merokok Kakal & & & & & & \\
\hline & Perokok & 9 & 42,9 & 5 & 11,9 & $5,550(1,555-19,811)$ & 0,009 \\
\hline & Tidak Perokok & 12 & 57,1 & 37 & 88,1 & & \\
\hline 15 & Peran Keluarga & & & & & & \\
\hline & Kurang Berperan & 15 & 71,4 & 17 & 40,5 & $3,676(1,188-11,376)$ & 0,021 \\
\hline & Berperan & 6 & 28,6 & 25 & 59,5 & & \\
\hline 16 & Teman Perempuan Perol & & & & & & \\
\hline & Banyak & 19 & 90,5 & 11 & 26,2 & $26,773(5,345-134,103)$ & 0,000 \\
\hline & Sedikit & 2 & 9,5 & 31 & 73,8 & & \\
\hline 17 & Teman laki-laki perokok & & & & & & \\
\hline & Banyak & 16 & 76,2 & 12 & 28,6 & $8,000(2,293-26,744)$ & 0,000 \\
\hline & Sedikit & 5 & 23,8 & 30 & 71,4 & & \\
\hline 18 & Peran teman sebaya & & & & & & \\
\hline & Kurang berperan & 13 & 61,9 & 21 & 50,0 & $1,625(0,558-4,730)$ & 0,371 \\
\hline
\end{tabular}


JOURNAL OF PUBLIC HEALTH INOVATION, VOL. 02 NO.01. DESEMBER 2021

DOI: $10.34305 /$ jphi.v2i1.353
Ciptaan disebarluaskan di bawah

Lisensi Creative Commons Atribusi-

NonKomersial-BerbagiSerupa 4.0

\begin{tabular}{|c|c|c|c|c|c|c|c|}
\hline & Berperan & 8 & 38,1 & 21 & 50,0 & & \\
\hline 19 & Keterpajanan iklan rokok & & & & & \multirow{3}{*}{$1,389(0,445-4,333)$} & \multirow{3}{*}{0,571} \\
\hline & Tinggi & 15 & 71,4 & 27 & 64,3 & & \\
\hline & Rendah & 6 & 28,6 & 15 & 35,7 & & \\
\hline
\end{tabular}

Tabel 2. Hasil Pemodelan Multivariat Determinan Perilaku Merokok Remaja Putri

\begin{tabular}{llll}
\hline \multicolumn{1}{c}{ Variabel } & \multicolumn{1}{c}{$\boldsymbol{p}$-value } & \multicolumn{1}{c}{ OR } & $\mathbf{R}^{2}$ \\
\hline Keyakinan & 0,108 & 22,264 & \\
Sikap & 0,173 & 0,028 & \\
Tingkat Stres & 0,132 & 23,119 & \\
Pekerjaan Ibu & 0,225 & 0,053 & 0,854 \\
Pekerjaan Ayah & 0,054 & 190,808 & \\
Akses Rokok & 0,047 & 6175,74 & \\
Uang Saku & 0,531 & 2,943 & \\
Perilaku Merokok Saudara & 0,202 & 8,165 & \\
Peran Keluarga & 0,190 & 8,244 & \\
Teman Perempuan Perokok & 0,029 & 4102,26 & \\
Constant & 0,015 & 0,000 & \\
\hline
\end{tabular}

\section{Pembahasan}

Variabel Keyakinan berhubungan secara signifikan dengan perilaku merokok remaja putri $(p=0,012)$. Responden yang memiliki keyakinan rendah berisiko untuk merokok sebesar 4,000 kali dibandingkan keyakinan tinggi (95\% CI 1,317-12,152). Hasil penelitian ini sejalan dengan penelitian yang dilakukan (Maarif, 2013) membuktikan ada hubungan bermakna antara keyakinan dengan perilaku merokok perempuan $(p=0,000)$.

Sikap memiliki hubungan erat dengan perilaku karena sikap merupakan kecenderungan untuk bertindak. Hal ini sesuai dengan hasil penelitian ini dimana sikap memiliki hubungan yang signifikan dengan perilaku merokok remaja putri ( $p=$ 0,000). Responden yang bersikap tidak baik berisiko untuk merokok 22,000 kali daripada responden yang bersikap baik (95\% CI 5,279-91,682). Hasil penelitian ini sama dengan penelitian (Maarif, 2013) yang membuktikan ada perbedaan bermakna antara sikap dengan perilaku merokok perempuan $(p=0,000)$.

Hasil bivariat menunjukkan ada hubungan bermakna antara pekerjaan ibu 
JOURNAL OF PUBLIC HEALTH INOVATION, VOL. 02 NO.01. DESEMBER 2021

DOI: $\underline{10.34305 / \text { iphi.v2i1.353 }}$

dengan perilaku merokok remaja putri ( $p=$ 0,031). Responden dengan ibu bekerja berisiko untuk merokok sebesar 3,520 kali dibandingkan dengan responden dengan ibu RT (95\% CI 1,090-11,371). Hasil penelitian ini sejalan dengan penelitian (Ardiansyah, 2010) menunjukkan ada hubungan antara pekerjaan ibu dengan perilaku merokok remaja $(p=0,000)$. Orang tua yang bekerja akan menghabiskan waktu yang banyak untuk pekerjaanya. Ketika kedua orang tua sibuk khususnya ibu, maka akan berkurang pengawasan dan kontrol pada anak. Apalagi pada masa remaja jika anak tidak diawasi maka anak akan mudah terpengaruh oleh lingkungan teman sebayanya, termasuk terpengaruh perilaku merokok teman sebayanya.

Pekerjaan ayah memiliki hubungan bermakna dengan perilaku merokok remaja putri $(p=0,004)$. Responden yang memiliki ayah bekerja tidak full berisiko untuk merokok sebesar 5,000 kali daripada ayah bekerja full $(95 \%$ CI 1,619-15,440). Pekerjaan ayah yang tidak full pada penelitian ini adalah pekerjaan selain pegawai negeri dan pegawai swasta. Kebanyakan ayah responden memiliki pekerjaan tidak full sebagai wiraswasta. Kota metropolitan merupakan tempat yang
Ciptaan disebarluaskan di bawah Lisensi Creative Commons AtribusiNonKomersial-BerbagiSerupa 4.0 Internasional

mendukung untuk berwiraswasta atau berwirausaha. Responden yang memiliki ayah yang bekerja tidak full lebih banyak pada kelompok remaja putri yang perokok daripada yang tidak perokok. Hal ini mungkin dikarenakan oleh beberapa hal, pertama ayah yang bekerja yang tidak full cenderung memiliki perilaku merokok. Perilaku merokok terkadang berhubungan dengan bisnis dan mitra kerja atau karena sudah kecanduan. Fakta menemukan bahwa terdapat hubungan yang signifikan antara sosial ekonomi dengan perilaku merokok pada remaja (Pampel et al., 2011).

Saat ini, rokok merupakan sebuah produk legal di Indonesia, dimana rokok dapat dengan mudah ditemukan termasuk warung-warung kecil dengan harga terjangkau. Sesuai dengan hasil penelitian (Tarupay et al., 2014) menunjukkan pada umumnya remaja mudah mendapatkan rokok yaitu dari teman atau membeli sendiri. Banyaknya penjual rokok yang menjual rokok dengan bentuk batangan, memudahkan remaja untuk membeli rokok. Menurut hasil riset KOMNAS perlindungan anak tahun 2011 menyatakan meningkatnya prevalensi merokok remaja di Indonesia salah satunya dipengaruhi oleh sangat mudahnya mendapatkan rokok. Pada 
JOURNAL OF PUBLIC HEALTH INOVATION, VOL. 02 NO.01. DESEMBER 2021

DOI: $\underline{10.34305 / \text { iphi.v2i1.353 }}$

penelitian ini, akses rokok berhubungan secara signifikan dengan perilaku merokok remaja putri $(p=0,000)$. Pada kelompok yang memiliki akses rokok mudah berisiko merokok 64,000 kali daripada akses rokok sulit $(95 \%$ CI 7,604-538,656). Hasil penelitian ini sejalan dengan penelitian di Sudan dan Ghana yang menunjukkan bahwa ada hubungan yang bermakna antara paparan industri tembakau dengan perilaku merokok remaja (Atari, 2014); (Mamudu et al., 2013) Veeranki, \& John, 2013).

Perilaku merokok kakak
berhubungan secara signifikan dengan perilaku merokok remaja putri $(p=0,009)$. Pada kelompok yang memiliki kakak perokok berisiko merokok 5,550 kali daripada yang memiliki kakak yang tidak perokok (95\% CI 1,555-19,811). Hasil penelitian ini sejalan dengan penelitian (Nurkamal et al., 2014) yang menemukan ada hubungan yang bermakna antara perilaku merokok keluarga dengan perilaku merokok remaja. (Erlindaningrum, 2014) menunjukkan bahwa jika ada saudara kandung yang merokok maka akan lebih besar lagi kemungkinan anak untuk jadi perokok. (Atari, 2014) menemukan jika remaja tinggal di rumah yang memiliki satu atau lebih orang merokok meningkatkan
Ciptaan disebarluaskan di bawah Lisensi Creative Commons AtribusiNonKomersial-BerbagiSerupa 4.0 Internasional

kemungkinan menjadi perokok 1,58 kali $(\mathrm{OR}=1,58,95 \%$ CI $(1,00$ - 2,49), dan remaja yang memiliki satu atau lebih orang tua yang merokok meningkatkan kemungkinan menjadi perokok 1,55 kali $(\mathrm{OR}=1,55,95 \% \mathrm{CI}(1,14-2,10)$.

Peran keluarga berhubungan secara signifikan dengan perilaku merokok remaja putri $(p=0,021)$. Pada kelompok yang memiliki memiliki peran keluarga yang tidak berperan berisiko untuk merokok sebesar 3,676 kali daripada yang memiliki peran keluarga berperan $(95 \%$ CI 1,188 11,376). Hal ini sama dengan penelitian (Tarupay et al., 2014), menemukan keluarga mempengaruhi perilaku merokok remaja karena kurangnya pengawasan orang tua, tidak tahu jika anaknya adalah perokok atau orang tua yang tidak melarang remaja merokok.

Perilaku merokok teman perempuan berhubungan secara signifikan dengan perilaku merokok remaja putri $(p=0,000)$. Pada kelompok yang memiliki teman perempuan perokok yang banyak berisiko merokok 26,773 kali daripada yang memiliki teman perempuan perokok yang sedikit (95\% CI 5,345-134,103). Hal ini karena interaksi yang lebih sering antara remaja perempuan dengan teman 
JOURNAL OF PUBLIC HEALTH INOVATION, VOL. 02 NO.01. DESEMBER 2021

DOI: $10.34305 /$ jphi.v2i1.353

perempuannya. Efek yang menyenangkan yang diperlihatkan oleh teman yang perokok serta ajakan atau tawaran teman untuk merokok, membuat remaja penasaran dengan rokok. (Reda et al., 2012) juga menemukan perilaku merokok remaja berhubungan dengan perilaku merokok teman (OR 8,14; 95\% CI 5,19-12,70). Hasil multivariat pada penelitian ini menunjukkan bahwa faktor dominan perilaku merokok remaja perempuan adalah akses rokok dan teman perempuan merokok.

Perilaku merokok teman laki-laki berhubungan dengan perilaku merokok remaja putri $(P=0,000)$. Hasil perhitungan OR menunjukkan responden yang memiliki teman laki-laki perokok yang banyak risiko merokok 8,000 kali daripada responden yang memiliki teman laki-laki perokok sedikit (95\% CI 2,393-26,744). (Kurniawati \& Widaryati, 2013) juga menemukan ada hubungan secara signifikan antara pengaruh teman dengan perilaku merokok remaja perempuan $(P=0,032)$. Remaja yang memiliki sebagian besar atau semua teman merokok meningkatkan kemungkinan menjadi perokok 2,55 kali $(\mathrm{OR}=2,55,95 \%$ CI (1,64 - 3,94)) (Atari, 2014).
Ciptaan disebarluaskan di bawah

Lisensi Creative Commons Atribusi-

NonKomersial-BerbagiSerupa 4.0

Internasional.

\section{Kesimpulan}

Faktor-faktor yang berhubungan secara signifikan dengan perilaku merokok remaja putri adalah keyakinan, sikap, pekerjaan ibu, pekerjaan ayah, akses rokok, perilaku merokok saudara (kakak), peran keluarga, teman perempuan perokok, dan teman laki-laki perokok $(P=<0,05)$. Determinan atau faktor yang dominan pada perilaku merokok pada remaja putri adalah akses rokok dan memiliki teman perempuan perokok.

\section{Saran}

Sekolah perlu lebih menggalakkan promosi bahaya rokok melalui media komunikasi, informasi, dan edukasi yang ada di sekolah guna meningkatkan kesadaran siswa-remaja putri akan bahaya merokok bagi kesehatan dan orang tua perlu menjalin hubungan komunikasi yang lebih baik dan aktif dengan remaja mengenai bahaya perilaku merokok bagi kesehatan, peningkatan pengawasan dan perlu terus memberikan contoh-contoh perilaku yang baik di kehidupan sehari-hari.

\section{Daftar Pustaka}

Ardiansyah, S. (2010). Faktor-Faktor Yang Berhubungan Dengan Perilaku Merokok Peserta Didik Pada SMA Al- 
JOURNAL OF PUBLIC HEALTH INOVATION, VOL. 02 NO.01. DESEMBER 2021

DOI: $\underline{10.34305 / j p h i . v 2 i 1.353}$

Mubarak Tanggerang Pada Tahun 2010. UHAMKA.

Atari, D. O. (2014). Gender Differences In The Prevalence And Determinants Of Tobacco Use Among School-Aged Adolescents (11-17 Years) In Sudan And South Sudan. The Pan African Medical Journal, 18(118), 1-10. Https://Doi.Org/10.11604/Pamj.2014.1 8.118 .3202

Erlindaningrum, A. (2014). Faktor-Faktor Yang Berhubungan Dengan Perilaku Merokok Siswa SMPN 17 Tanggerang Dan SMP Yuppenstek 2 Tangerang. UHAMKA.

Kemenkes RI. (2014). Perilaku Merokok Masyarakat Indonesia (Pp. 1-11). Kemenkes RI.

Kemenkes RI. (2018). Akibat Asap Rokok. Kemenkes RI.

Kemenkes RI. (2019). Beberapa Masalah Yang Muncul Bagi Remaja Perokok. Kemenkes RI.

Kurniawati, F., \& Widaryati. (2013). Hubungan Dukungan Keluarga Dengan Pelaksanaan Mobilisasi Pada Pasien Pasca Operasi Appendicitis Di RS PKU Muhammadiyah Yogyakarta. Naskah Publikasi.

Maarif, M. (2013). Faktor-Faktor Yang Berhubungan Dengan Perilaku Merokok Pada Wanita Usia Subur Pengunjung Kantin Gedung Perkantoran Wisma SLIPI Jakarta 2013. UHAMKA.

Mamudu, H. M., Veeranki, S. P., \& John, R. M. (2013). Tobacco Use Among
Ciptaan disebarluaskan di bawah

Lisensi Creative Commons Atribusi-

NonKomersial-BerbagiSerupa 4.0

Internasional

School - Going Adolescents (11-17

Years) In Ghana. Nicotine And Tobacco Research, 15(8), 1355-1364. Https://Doi.Org/10.1093/Ntr/Nts269

Nurkamal, E., Nursalim, \& Darmawan, S. (2014). Faktor-Faktor Yang Mempengaruhi Kebiasaan Dan Perilaku Merokok Siswa Kelas XII SMAN 2 Pare-Pare. Jurnal. STIKES Nani Hasanuddin, 4(2), 169-175.

Pampel, F. C., Denney, J. T., \& Krueger, P. M. (2011). Cross-National Sources Of Health Inequality: Education And Tobacco Use In The World Health Survey. Demography, 48(2), 653-674. Https://Doi.Org/10.1007/S13524-0110027-2

Reda, A., Moges, A., Yazew, B., \& Biadgilign, S. (2012). Determinants Of Cigarette Smoking Among School Adolescents In Eastern Ethiopia: A Cross-Sectional Study. Harm Reduction Journal, 9(39). Https://Doi.Org/10.1186/1477-7517-939

Tarupay, A., Ibnu, I. F., \& Rachman, W. (2014). Perilaku Merokok Maharemaja Putri Di Kota Makassar. UNHAS. 